\title{
Path Analysis of Rural Landscape Protection and Creation under the Guidance of High-Quality Development of Rural Tourism A case study on Tianfu Red Valley in Chengdu
}

\author{
Ming Xiang ${ }^{1, a^{*}}$, Yan $\mathrm{Xu}^{2}$ \\ ${ }^{1}$ Chengdu Polytechnic, Chengdu, Sichuan, China \\ ${ }^{2}$ Shandong Institute of Commerce and Technology, Jinan, Shandong, China
}

\begin{abstract}
In the context of high-quality development of rural tourism, the design of rural landscape is of great significance for inheriting regional culture and protecting local ecology. From the perspective of the planning and design of rural tourism, the authors divide the elements of rural landscape into four aspects: "original" rural environment, "original" rural architecture, "original" production and life, and "original" folk customs. Based on that, the authors then propose to boost the protection and creation of rural landscape from four aspects which are: continuation of the traditions and architectural styles of western Sichuan, protection of rural natural ecology, inheritance of regional traditional culture, and implementation of the strategy of "cultural innovation + rural tourism", so as to realize the sustainable development of rural landscape.
\end{abstract}

\section{Literature review}

\subsection{High-quality development of rural tourism}

The development of rural tourism is a way to promote rural revitalization and is conducive to proper rural industries, ecologically livable environment, rural civilization and governance, and better living conditions.

The report delivered at the 19th National Congress of the Communist Party of China made a major historical judgment that " China's economy has been transitioning from a phase of rapid growth to a stage of high-quality development. " The Central Economic Work Conference continued to focus on promoting high-quality development from 2017 to 2018 . Therefore, we must grasp the lifeline of quality and lead the rural tourism industry to a development pathway which stresses the quality, specialization and advancement, guiding rural tourism to the road of high-quality development.

Zhou (2016) ${ }^{[1]}$ pointed out that in the transformation process of rural tourism, there are problems like inadequate environmental protection of resources, insufficient innovation of rural tourism products, unclear local cultural characteristics, insufficient coordination of the main elements, and insufficient industrial development motivation. Song and Chen (2017) ${ }^{[2]}$ believe that improving the quality and efficiency of rural tourism requires diverse patterns, defined subject, highlighted local features and ecology, and specified communities. The high-quality development of rural tourism needs to be rooted in a good ecological environment and a profound cultural heritage, which requires people to preserve and inherit the rural traditional farming culture, folk culture and other characteristics while protecting and managing the rural ecological environment, and to create something different from towns. Harmonious natural and humanistic landscapes will enrich the connotation of the village and diversify its functions, promote sustainable development, promote rural revitalization and the establishment of beautiful villages.

\subsection{Rural landscape}

The research on rural landscape was first carried out in Europe, starting from cultural aspects. The research on rural landscape design started late in China, and the research theory and methods are still in the exploratory stage, but has gained more and more attention. Most projects of building rural landscape are the result of villagers' voluntary actions or village cadres' organization, but with no unified planning guide. As a result, there are problems such as blind reconstruction and expansion, mixed styles, homogenous appearance, and overurbanization.

As an important part of rural construction, rural landscape has the characteristics of regional design, human factors and original ecology [3]. From the perspective of tourism, the rural landscape is one that is finally formed by the transformation and upgrading of tourism and art, and on the basis of the inherent landscape and village patterns. Apart from the same beauty and ecological functions as the general landscape has, it also has certain economic significance.

According to Xiong ${ }^{[4]}$, who studies the design methods of rural landscape, the design of rural landscape 
needs to maintain the original ecology as much as possible, and fully reflect the characteristics of the local soil, and region-based humanistic care will better promote the development and progress of rural areas. Jiang and $\mathrm{Ma}^{[5]}$ take the traditional Tibetan settlements in Gannan as an example to study the rural landscape under the transformation of the tourism industry, and conclude that the tourism landscape needs to be studied in many aspects such as folk customs, humanities and characteristics.

With a focus on the research of the constituent elements of the rural landscape, Li et al. ${ }^{[6]}$ propose a fourrule vernacular landscape system composed of elements of ecological landscape, production landscape, life landscape, and lives landscape. These classification methods cover most of the elements of the rural landscape, but they all start from the perspective of the garden landscape, and the rural landscape elements cannot be fully identified and effectively protected in the planning and design of rural tourism.

\section{Overview of the study area}

Qionglai is a city located in the southwest of Chengdu, and adjacent to Dayi County in the north, Xinjin District and Pengshan District of Meishan City in the east, Yucheng District and Lushan County of Ya'an City in the west, and Pujiang County and Mingshan District of Ya'an City in the south. Besides, it is 65 kilometers away from the core part of Chengdu, within the half-hour economic zone.

\subsection{Analysis of the status quo of the development of rural tourism in Chengdu}

According to Table 1 and Figure 1, it can be found that the Chengdu urban agglomeration has a population of 23.53 million, more than 6 million private cars, and a per capita GDP of more than 7000 US dollars, providing convenient self-driving transportation and a solid economic foundation for family travel. The potential needs for rural tourism are continuously released, which provides good market conditions for the high-quality development of Qionglai tourism.

Table1. Statistics of economic indicators of Chengdu urban agglomeration in 2018

\begin{tabular}{|l|l|l|l|l|}
\hline & $\begin{array}{l}\text { Permanent } \\
\text { population } \\
\text { (ten } \\
\text { thousand } \\
\text { people) }\end{array}$ & $\begin{array}{l}\text { GDP } \\
\text { per } \\
\text { capita } \\
\mathbf{1 0 0} \\
\text { million } \\
\text { yuan) }\end{array}$ & $\begin{array}{l}\text { Disposable } \\
\text { income of } \\
\text { urban } \\
\text { residents } \\
\text { (Yuan) }\end{array}$ & $\begin{array}{l}\text { Private car } \\
\text { number } \\
\text { (Ten } \\
\text { thousand } \\
\text { vehicles) }\end{array}$ \\
\hline Chengdu & 1429.8 & 94782 & 42128 & 487.52 \\
\hline Deyang & 387.0 & 62569 & 24701 & 49.9 \\
\hline Mianyang & 536.20 & 47538 & 34411 & 66.14 \\
\hline In total & 2383 & - & - & 603.56 \\
\hline
\end{tabular}

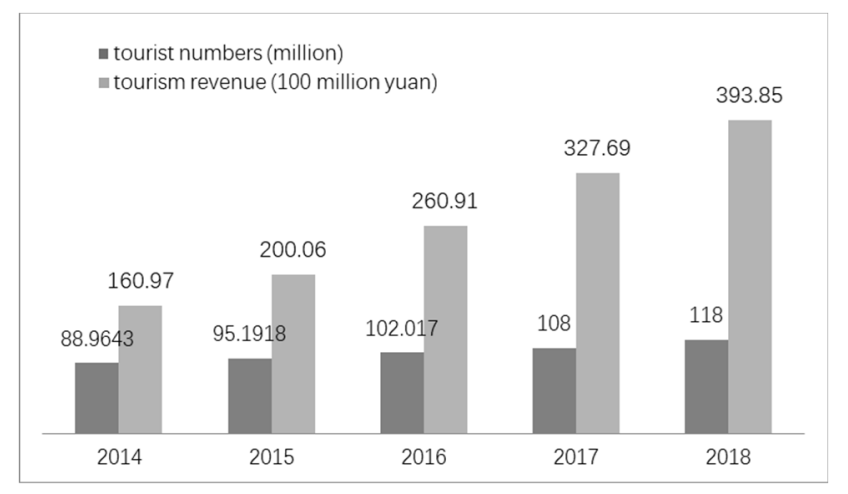

Fig 1. Statistics of tourists visiting Chengdu's rural area and tourism revenue from 2014 to 2018

In 2019, Qionglai accepted 16.31 million tourists and achieved a total tourism revenue of 16.90 billion yuan, with a year-on-year increase of $26.0 \%$ and $152.9 \%$ respectively. Relying on the good ecological environment and abundant tourism resources, Qionglai has achieved rapid growth in tourism and accelerated to help the poverty-stricken people to get rid of poverty.

\subsection{Brief Introduction of Tianfu Red Valley, Chengdu}

Tianfu Red Valley is located in Tiantaishan Town, 120 kilometers away from Chengdu City. The initial project of Tianfu Red Valley Vision Park, with an investment of 36 million yuan, is located in the original Dajiao paper factory plot in Jingkou Village, covering 11,722 square meters, and is divided into three sub-zones: the happy vision zone, the farming and recreational living zone, and the forest living and health preservation zone. It is a place for concentrated display and experience of the main business types of Tianfu Red Valley project.

\subsection{Development status of Chengdu Tianfu Red Valley}

Tianfu Red Valley · Vision Hall was awarded as the second batch of outstanding examples of rural architecture by the Ministry of Housing and Urban-Rural Development; Gengdu Taoyuan Resort was rated as Five Star Country Hotel and Creative Culture Corner by Sichuan Tourism Standard Evaluation Committee, and was named as Joint Innovation Base by Sichuan Traditional Culture Promotion Association, Chengdu Traditional Culture Protection Association, Culture and Tourism Professional Committee.

From its launch to May 2020, Tianfu Red Valley project has held nearly 30 activities, including farming lecture halls, township construction forums, organic agricultural technology lectures, international health consulting and public welfare services, and more than 150 batches of special investigation groups from all over the world have been received, with more than 26,000 tourists, the tourism income of about 9 million yuan, and more than 8,000 people benefited ${ }^{[12]}$. 


\section{Analysis of rural landscape elements}

Rural landscape is a relative concept compared with urban landscape. From the perspective of rural tourism planning and design, the authors classify the elements of rural landscape and analyze the specific elements in combination with the actual resources of Tianfu Red Valley, Chengdu.

Table2. Analysis of rural landscape elements

\begin{tabular}{|l|l|}
\hline Elements of rural landscape & Forms \\
\hline \multirow{4}{*}{$\begin{array}{l}\text { "Original" } \\
\text { rural environment }\end{array}$} & landform \\
\cline { 2 - 2 } & Water \\
\cline { 2 - 2 } & Animals \\
\cline { 2 - 2 } $\begin{array}{l}\text { "Original" } \\
\text { Vernacular Architecture }\end{array}$ & Plants \\
\cline { 2 - 2 } $\begin{array}{l}\text { "Original" } \\
\text { Production and Life }\end{array}$ & Residential building \\
\hline & Farmland \\
\cline { 2 - 2 } & Woodland \\
\cline { 2 - 2 } & production tool \\
\cline { 2 - 2 } & Living utensils \\
\hline \multirow{2}{*}{$\begin{array}{l}\text { Folk Customs } \\
\text { Folinal" }\end{array}$} & revolutionary Ruins \\
\cline { 2 - 2 } & Nostalgia \\
\hline
\end{tabular}

\section{1 "Original" rural environment}

In the rural landscape, the pastoral environment is the most basic and precious component. The "authentic" pastoral environment is a natural ecological environment formed by the regional topography, water resources, animals and plants. Tianfu Red Valley is backed by the Tiantai Mountain National Scenic Area, and the terrain is in the mountain valley zone from southwest to northeast. Zhenxi Mountain, Tiantai Mountain, Nanbao Mountain and other three mountains are sandwiched by a valley. It enjoys a good ecological environment with Wenjing River flows through this place and mountains on the back. In the development of rural tourism, the buildings are integrated into the mountains and rivers, and they are scattered and distributed in harmony and unity with the environment.

\section{2 "Original" Vernacular Architecture}

Vernacular architecture is the most distinctive symbol of rural areas, which is constituted by villages and dwellings. It is usually reflected in the appearance and decoration, the use of local materials, and the inheritance of local architectural skills. Western Sichuan architecture has existed in Tianfu Red Valley for hundreds of years. The architectural styles of western Sichuan residential buildings, bucket-type building structures, local building techniques, natural stone such as adobe bricks, blue tiles, pebbles, red sandstone, bluestone, and local bamboo and wood are used. The combination of tradition and modernity revitalizes the old buildings on the ground, creating a rural landscape with local characteristics.

\section{3 "Original" production and life}

The production and living elements reflect the functional characteristics of the rural landscape, including farmland, woodland, production tools and living utensils.

Farmland is the landscape with the largest land area in the countryside. Creative agriculture and sightseeing agriculture that combine traditional productivity with modern aesthetics are new directions for agricultural development. The land where Tianfu Red Valley is located is slightly acidic and neutral soil which is thick and soft. There are a large amount of wild yam growing in local hills and mountains. Qionglai, the home to Tianfu Red Valley, is a leading city for the bamboo industry identified by Chengdu and a key forestry development city in Sichuan Province. The bamboo industry has obvious advantages. The predecessor of Tianfu Red Valley was the Qionglai State-owned Dajiao Paper Factory. The abundant bamboo forest resources provided sufficient raw materials, mainly producing writing paper, yellow paper and other paper products.

Agricultural production tools are an indicator of the progress of social productivity, including plows for arable land, iron hoe for weeding, sickles for harvesting, and stone mills for processing. Traditional rural life utensils are mostly handmade products. Horses, brooms, dustpans, etc., have strong local characteristics and are a display of traditional folk skills.

\section{4 "Original" folk customs}

"Original" folk customs focus more on non-material factors, including folk songs, folk songs, folk handicrafts, and folk festivals that have been passed down through history, as well as the harmony between neighbors and the nostalgia in people's hearts, reflecting the rural landscape Spiritual characteristics. Tianfu Red Valley takes rural courtyards and rural villages in western Sichuan as carriers, and mainly highlights the resources of rural beauty, and nostalgia. There are three forming buildings of the Soviet government, two sites of the Red Army hospital, one site of the Red Army trenches, and one Red Army Long March Qionglai Memorial. There are also stories of a pole and cloth coins, featuring enriched red tourism resources.

\section{Path analysis of rural landscape protection and creation}

\subsection{Continuing the traditional architectural style of Western Sichuan}

In order to create the "original" vernacular architecture, Tianfu Red Valley divides the buildings in the area into two major categories: one requires renovation and reconstruction, and the other needs demolition and new construction and the principle is to keep the characteristics of the original buildings. For houses with traditional styles and historical and cultural values, such as the dormitory and office building of the Dajiao Paper Mill, protective renovation will be carried out; newly built houses are in 
harmony with the traditional style and integrated into the surrounding environment. The overall style is based on the continuation of the western Sichuan residential style, and local materials are used as much as possible, and modern materials are used locally to reflect the new architectural characteristics.

\subsection{Protecting rural natural ecology}

Adhering to the principle of giving priority to ecology, Tianfu Red Valley combines the local natural ecological environment, pays attention to conformity to nature, rational layout, reproduces the "original" pastoral environment, and ensures the sustainable development of rural landscape design. Mountain Courtyard, Relaxation Courtyard, and Riverside Restaurants in the area have confirmed its harmonious living environment.

\subsection{Inheriting regional traditional culture}

Integrating the surrounding ecological environment, rural tourism resources, and living elements in West Sichuan, Tianfu Red Valley relies on the "original" folk customs and "original" production and life to provide authentic West Sichuan life experience and advocate an environmentally friendly lifestyle. In the design of the regional landscape sketch, the project will retreat from the historical stage of the ploughshares, wooden forks, scarecrows, plain wooden fences, and bamboo lanterns under the corridors, reflecting the legacy of traditional farming. Rooted in rural life, local customs, coupled with delicious rural ingredients and supporting play, the project site quickly goes viral on the Internet.

\subsection{Implementing the "Cultural Innovation + Rural Tourism" strategy}

With the guidance of cultural creativity + rural tourism strategy, Tianfu Red Valley makes use of local features like the unique local folk culture, farming culture, and architectural culture to create a distinctive homestay creative culture, farming culture, and organic agricultural culture. Cultural and creative wisdom has driven the joint development of primary, secondary and tertiary industries, and has embarked on a rural tourism road with unique local differentiation.

\section{Conclusion}

Conducting research on the protection and creation of rural landscape, exploring and combing the elements of rural landscapes, and promoting the construction of rural traditional culture are of great significance to the revitalization of rural economy, the inheritance of regional culture, and the protection of local ecology.

Based on the identification, protection and utilization of rural landscapes, combined with the reality of Chengdu Tianfu Red Valley, the protection and creation of rural landscapes should carry on the traditions and architectural styles of western Sichuan, protect rural natural ecology, inherit regional traditional culture, and implement cultural creativity + rural tourism. In that way, we will promote the modernization, diversification and vivid expression of rural traditional culture, and realize the sustainable development of rural landscape.

\section{References}

1. Zhou X.M. Rural Tourism Transformation and Upgrading Strategy under the Background of Industrial Integration[J]. Agricultural Economy, 2016(07): 17-19.

2. Song H.J, Chen M. Analysis of the Path to Improve the Quality and Efficiency of Rural Tourism under the Background of Rural Revitalization Strategy[J]. Shanghai Economics, 2017(06): 17-24.

3. Lu J.F. Research on Rural Landscape Planning and Design under the Background of New Countryside Construction [D]. Henan University of Science and Technology, 2017.

4. Xiong X.J. Research on the Beautiful Rural Landscape Design with Local Characteristics [J]. Rural Science and Technology, 2018 (15): 51-52.

5. Jiang Y, Ma J. Research on Rural Landscape Planning under the Transformation of Tourism IndustryTaking Gannan Tibetan Traditional Settlement as an Example [J]. Architecture and Culture, 2017 (5): 179180.

6. Li P.B, Lei D.P, Zhang L.J, Wu J. Research on the Elements of Rural Landscape [J]. Ecological Economy, 2016 (32): 224 227. 